$$
\mathrm{v}^{2}=\frac{1}{4-1}\left(110-\frac{2}{4}\right)=\frac{109.50^{1}}{.3}
$$

となる。

この分散比をとると

$$
\mathrm{F}=\frac{184.75}{109.50}=1.68<9.18
$$

となる。

$\mathrm{F}$ 一分布表 求めると 9.18 であるら，母分散方等しい母集團の標 本で京りながら，分散比ぶ 9.18 上上にすなるとと 100 四中 5 包位しかないことが分る。我々の觀測值の分散比 が 9.18 以上ならば，母忿散㭁等しい母集團の標本と乙 ては，めつたに起ら婸合之斷じ得るが，今得た值 1.68 㤬らかに 918 より小さい。

從つて, 錯視量の母分散は，左右で有意な差仯認め，5 れない (有意な差”とゆうのは, 術語であつて, 有意

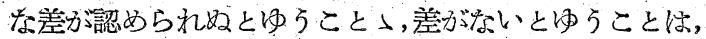

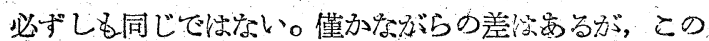
程度の大さの標本では，檢出できぬとゆう場合があるか 5.)

\section{2. 二つの標本平均值の差}

同一正規时集團加 偏分散 $\mathrm{u}^{2}$, 友び夫々 $\mathrm{M}, \bar{\nabla}, \mathrm{v}^{2}$ の三標本を抽出すると, その三つを合した場合の共通不偏分散 $\omega^{2}$ は,

$$
\begin{aligned}
\omega^{2} & =\frac{1}{(N-1)+(M-1)}\left[(N-1) u^{2}+(M-1) v^{2}\right] \\
& =\frac{1}{N+M-2}\left[s\left(X i-\bar{X}^{2}\right)-s(y i-\bar{y})^{2}\right]
\end{aligned}
$$

飞舉光々る。

そして，標本本均值の差 $\overline{\mathrm{x}}-\overline{\mathrm{y}}$ が， まる值以上とな

1） 109.50 そ 109.5 とは，實用數學では區別して使 109.50 は小數 3 位が不磪かなこと１09.5 は小数 2 位が不磪かなとをを示す。
る確率は

$$
F=\frac{(\bar{X}-\bar{y})^{2}}{\left(\frac{1}{N}+\frac{1}{M}\right) \omega^{2}}=\frac{(\bar{X}-\bar{y})^{2}}{\omega^{2}}\left(\frac{M N}{M+N}\right)
$$

が， ある値以上となる確率で代表され，その值が $\mathrm{F}_{0}$ 以 上となる確柔は

$$
\mathrm{n}_{1}=1, \mathrm{n}_{2}=\mathrm{M}+\mathrm{N}-2, \mathrm{~F}=\mathrm{F}_{0}
$$

とした $\mathrm{F}$ 一分布函數の值であらわせること亦證明されて W.

前項の檢定で母分散に虻差が認められ婸合に，この

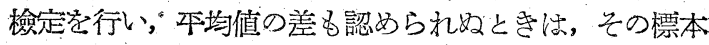
注同一母集團に屬すると認められる（註一この检定法 は，母分散才゙等しいこと学認めた上で，母本均の差の檢 定をするので，母分散の等しいことゔ認められ婸合の

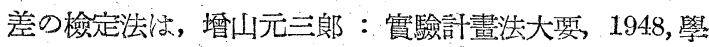
術圖書出版飞紹介されている。)

次に，先に分散比に有意の差壳認め得なかつた MüllerLyer 錯視量の例をとり，つがいて本均值の差を检定し てみよ5。

$$
\begin{aligned}
& \omega^{2}=\frac{1}{M+N-2}\left[\Sigma(X i-\bar{X})^{2}+\Sigma(y i-\bar{y})^{2}\right] \\
& =\frac{1}{4+4-2}[184.75+109.50] \\
& =\frac{294.25}{6} \\
& (\overline{\mathrm{X}}-\overline{\mathrm{y}})^{2}=(72.75-70.50)^{2}=5.0625 \\
& \mathrm{~F}=\frac{5.0625}{\left(\frac{1}{4}+\frac{1}{4}\right) \times \frac{294.25}{6}}=0.206 \\
& \mathrm{~F} \text { 一分布表より } \mathrm{P}\left(\mathrm{F} \geqq \mathrm{F}_{0}\right)=0.05 \text { に對し } \\
& \mathrm{n}_{1}=1, \mathrm{n}_{2}=6 \text { のとさ } \mathrm{F}_{0}=5.99
\end{aligned}
$$

今算出した $\mathrm{F}$ と比較すると， F=0.206>5.99 であるか ら，目集團が異ると恃考它られぬ。

(1944 年 9 月受稿 1948 年改䛅)

\title{
Max Wertheimer (1880-1934)
}

中 村 克 已

\section{I}

Max Wertheimer は 1880 年 Prag で生れた。はじめ はPrag 大學で法律を學び,初期になされた證言の心理學 的䂧究が後年の真理や思考の問題についての關心の萠芽 を示していることがNewmanによつて指摘されている。 (E. B., Newman : Max Wertheimer : 1880-1943. The American Journal of Psychology 57, 3, 1944)。 後 Prag, Berlin, Würzburg の諸大學に學び, 1904 年 Külpe のもとにWürzburg 大學で summa cum laude (最高の學位)を得た。
1912 年に發表された運動視の實驗的㸴究（》Experimentelle Studien über das Sehen von Bewegung( ) セザ視知覺の領域だけの一つの特殊研究にとどまらず， ひろく一般に意識現象の領域にわたつてゲシタルト心理 學の樹立，またとこに認められる法則性多心理學けシけで なく，その原理は他の諸領域にも見られるとい5理論を さららに展開するゲシタルト理論の樹立への最初の出發點 となつたものとして重要な意義をるつるのでが，この呼 究の成立の機緣について Newman が次のよ5な事實の あつたことを述べている。 ヴィーンからラインランド の汽車の旅の中で, Wertheimer は見えの運動の實驗の 
プランを考えついた。そこで次の停車場でその旅行を中 止して,すぐにその考案学試驗することにした。この降 りた都市がたまたま Frankfurt am Main 艺つた。ホテ ルに荷物完置いて，玩具のストロボスコープを買いに行 きっホテルにかえつて實驗裝置をととのえた。さらに大學 で Schumann にあい, Schumann のストロボスコープ を提供されて實驗にかかり，Köhler と Koffka と赏被驗 者として數ヶ月後に實驗が完成したといらのだ。( Newman 前出)。運動悓の實驗的政究の發表された同じ 年にな和自然民族の數形態安摭つた，とくに思考につい て示唆するところの多い民族心理學的䂺究 (》Ueber das Denken der Naturvölker, Zahlen und Zahlgebilde《) 分登表されている。

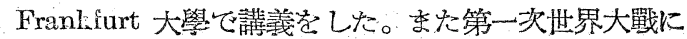
際しては戰拿のための㱏響心理學の應用方面の研究にし たがつた。この意味て戰爭に參加はしたが, 第一線に出た ユダヤ人では尔いというので, 後にナチスの時代にドィ

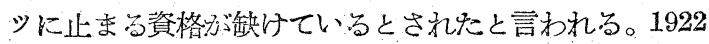
年・Berlin 大學の員外敎授となつた心゙，乙の頃，雜誌 》Psychologische Forschung《荌出して，亮の編集者の 一人となりがシタルト心理學の問題への最もよい手引 价ろちとして Köhler 子推薦している Punkt-Arbeit の 名で呼ばれている》Untersuchungen zur Lehre von der Gestalt《穵同誌に發表した。安た同樣に，この時期に，思考 心理學と論理學との兩領域を扱つているとWertheimer 自身のいら》Ueber Schlussprozesse im produktiven Denken《艺ささ運動視の實驗的砋究と自然民族の思考 の研究とともに收錄した論文集 (Drei Abhandlungen zur Gestalttheorie $($ ) やまたゲシタルト心理學の法則性 に物ける原理が心理學だけでなく，穴の他の領域にも見 出されることを諮いた 》Ueber Gestaltheorie《が出てい る。

1929 年からは再び Frankfurt 大學飞かえり, Schumann の後を特气つて，その正敉授となつた。この時期

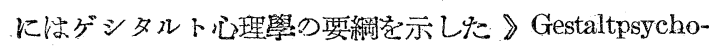
logische Forschung 《と Schumann 紀念論交として書か れたやはり Punkt-Arbeit と呼ばれてるよいと思われ る點や線やの關係によつて法則性を精雅に把捉すること のなされている》Zu dem Problem der Unterscheidung von Einzielinhalt und Teil 《と刃゙發表されている。

Wertheimerのドイッ時代の法わり頃には大學で講義 そしない時多゙多く，賜层でスウィスの Ascona に滞在し ていたり，またナチス犻政權をとつて後法再び講義をす るととなく, 1933 年 New York に行くまでチェッコス ロヴァキアのMarienbad に滞在していをりした。しかし そんな時も一つの中心をら, 筆者为 Wertheimer に 心じめて Ascona て直接師事した時は, von Hornbostel が來ていたし， 奆 Duncker も來るとのことだつた。

こつ時期の Wertheimer の興味梳大體, 論理學の研 究にあつたと言える。Frankfurt 大學に和ける最後の講

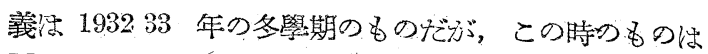
Metzger と共同の心理學演柏のほかには論理學の講義と

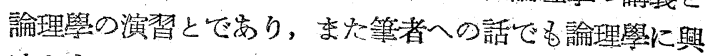
味をもつているとのことだつたし，また時間が岁つたら Grundriss der Logik とでもいう題の書物壳書こうかと 思つているとのことだつた。その論理學の講義仙論理學 の諸事項に對してゲシタルト理論について示唆夌與えて いるものであり,論理學つ演習ではぞの》Uber.Schlussprozesse im produktiven Denken 《についてゲシタル 々論理學忐”，また Carnap の》Abriss der Logistik《な どヴィーン學團の論理學引゙扱われた。な物心理學の演替 ではLewin の》 Die psychlogische Situation bei Lohn und Strafe $《 \varphi$ Wertheimer $の\rangle$ Ue'jer das Denken der Naturvölker そ，その他多くの交献の紹介批評引な された。 Marienbad では筆者に對して思考心理學々論 理學とに和ける種々の事項について數ケ月にわたつて每

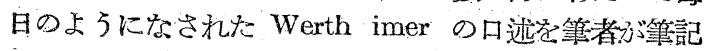
した。この筆記老 Wertheimer 蛅 New York へもつて 行くとのことだつた。

Marienbad 滯在中, New York の New School for Social Research 凹行くことぶきまり，後它この學部が 出來て，その敉授となつた。この時期に保 New York へ5つつた翌年, 真理を全體的機能的に見る》 On Tr-

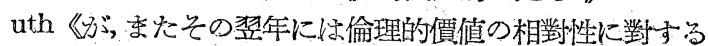
問題学提起している》Sorme Problems in the Theory of Withics 《が發表されている。な物等者への返簡による

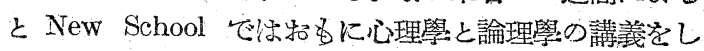
て物り、そのほかに Harvard, Princeton, Cornell 及び Columbia でも講義をするとのことでめり，そして New York 几行つてからの研究はうまく進んでいらのこと ぞつた。な特上記のほか 1941 年に〉Gestaltpsychology 《(in》Living School of Philosophy 《) やさらに最近, 生產的思考の研究の出版方報じられている。 Newmank よるとWertheimer は New School ではしばしば生產 的思考について講義究したこと，また社會科學者の一團 と密接な關係を当つ上らになつたこと名言われ，そして ゲシタルト心理學恬ら゙シタルト倫理學になつたと言われ ている。(E. B. Newman 前出)。Wertheimer はかなり ま完から健康にめぐをれず，Marienbad でも心臟と眼 とがよくなかつたが, Newman によると(前出) 1943 年 NewYork で死んぞのは心獩病によると言われる。

\section{I}

これるで心的事賽の解明を試みたすのに一方，心的要 素の機械的結合による要素儿理學と他方，これに對して この行き方では心的事實の本質加つかめていないとし て，灰とえぱ了解というような科學的でなく，そして主 觀的なものによるととの二樣の行き方があつたのに對 してWertheimer は上から下へ」の行き方壱とつて心 的事實を全體過程の相の下に見て，意識現象の备部分の 
間の機能的含意的な相屬留俰系瑯事的にそ意識現象の 層に現れていることを認めることによつて，心的惠實の 解明にとつて新しい行き方を示した。そして部分が機能 的含意的に全體によつて規定されるこうした關係分心理

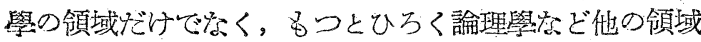
にも原理的に見出されえること走した。

こうした理論起をてることについて Wertheimer 虫次 のよ5尔見解安もつている。ゲシタルト理論ば具體的な 研究業績の中から生れたもので, 心理學, 民族心理學,

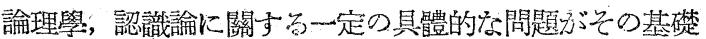
を與えたもので，それらの研究引゙次第に根本的主要的な 點に集中してて來たわけだ。そしてゲシタルト理論忹ただ に䂰究業績の中から生じるばかりでなく，政究業績のた

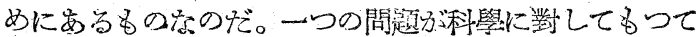
來られるとい5ので岕なくて, 具體的な科學的業績の中 にしかじかのこと筧られるという，いゃしかじかのこ とが見られるのでなくて，具體的度关の崵合にある內的

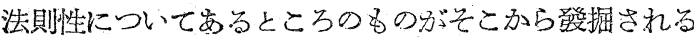
といらことになるの隹。でからしかじかの場合学見，そ れを手際よく體系ずけ，父れぞれの科目に區切り，そし て世界を概觀しようとするので惊なくて，現實にそこに 横わつているものの中突さ進んで行くとい5ふらにす るので。これは一般性について云々されらテーゼではな くて，實に本質に突き進もうとの意志で㐫り，動的なる

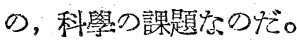

Wertheimer がこういう見解学昌つていることからし $\tau$ Wertheimer の賽際に示した諎業績学見る時,この見 解が如實に示されていると見ることが出來よう。さきに 示された Wertheimer の諸研究はどれ寻體系的にまと

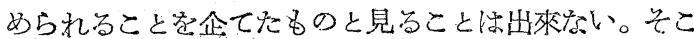
にあつては具體的な諸問題からして法則性の發掘が企て られていると見られる。運動視の實騟的趼究に特ける 現象,グシタルトの理論の砳究での園末れの要因，よい カーヴの要因，その他の諸要因，個的內容と部分との區 別の問題についての研究に招げる圖形についての機能的 全體關係の精密な把捉なぞ知覺心理學の場合にめつてこ こから內的法則性について劣るところのるの發掘する ことがなされて物り．自然民族の思考の㸴究に和ける數 形態の結構の問題, 推理過程の跖究に和ける S 加ら P への含意的相屬關係，末た筫理についての矿究で全體的 機能的關係に和いての制斷の六對象との一致分たてら れていることなどはこの內的法則性がさらに思考心理學

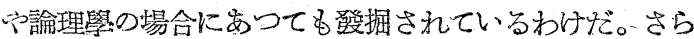

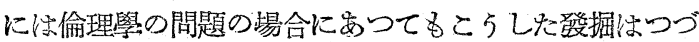
けられていると言える。このようにして Wertheimerの 研究部分的に種々の具體的專象, 種々の具體的䦗題の 場合加らして次第に根本的な點に集中して來ているつの代 と言えよう。

こちしてゲシタルト理論にあつて仿一般的な根本テー ゼをなげそれぞれ個々の領域にあてはめるというのでは
ない。すなわらゲシタルト理論をたてるについては一つ の原理をたてて，これによつて諸事項，諸問題を說明し

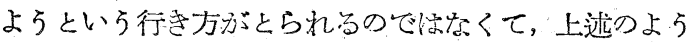
に部分的な具體的な雪像のところに見出される內的法别

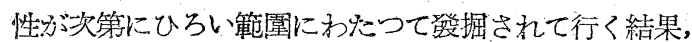
一つの理論がたてられて行くことになるわけげ。

Wertheimer に上つて書かれたもの结どれも短い論文

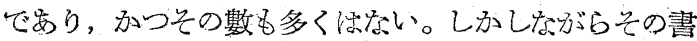
かれたものはその交體の簡潔なのと安いまつて短い交章 の中に深い含堛，豊富な内容の盛られた，元して生々と

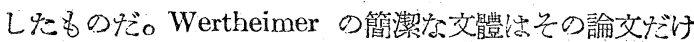
でなく，兮の害簡に岕つて名同樣に現れている。

ところで Wertheimer 少゙表現について如何に不都合 を感じたかが Köhler に上つて述べられている。すなわ ちとの理論に反對の人々を說得するために法 Wertheimer の主張犺書か机なければならず, そしてこのために は普通の言語务”使用されれなければならないのゲが，この 言語で吕 Wertheimer 方゙言いたいと切實に思うことを 表現すること出出來ないの苂。といらの蜆代の言語仙 「下から」の記述犯される上5に出來ているから，この

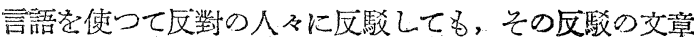
以反對の人々の先入見によりて當然解釋されることにな

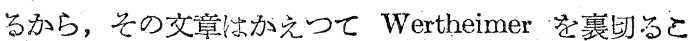
とになるから䠜。それ代から Wertheimer の書いたもの によつては年のすぐれた精神の適切な印象がわれわれに 與えられえないの代。矢れで Wertheimer 号交章のこ

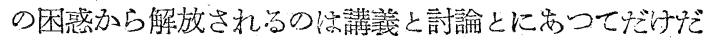
つた。この時に法そうした困難などは嵐によつての上う に吹き虫らわ机るの苂。Köhler はこのように述べてい る。(W. Köhler : Max Wertheimer 1880-1943, The Psychological Review 51, 3, 1944)。畫玑たものによ つてボけでは十分でなく，午の著者のことばを直接㯖く ことによつてその所說西明かにされえるということ结普 通にも見られるところでが、Wertheimer に专つてはこ

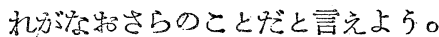

簡潔はただにその文體げけにとどあらない。Werthei-

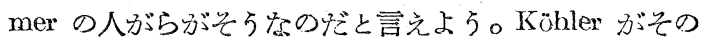
偉大な簡潔と精淮との點で Wertheimer 艺聖フランシ スコに比しているのは (W. Köhler 前出)なるほどと うなずくことが出來よう。われわれ隹 Wertheimer の

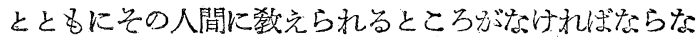
理論いのではないか。いまゲシタルト理論の創始者に對

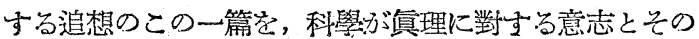
興亡の運命をともにすることを說いたこの學者の次のこ とばをもつて特わろう：「科學你覓理への意志に根ざ ษ」。 